\title{
Family firms and the divestment decision: An agency perspective
}

\author{
Alain Praet* \\ Centre For Informatics, Simulation and Modeling (CIMS), Hogeschool-Universiteit Brussel (HUB), Warmoesberg 26, 1000 Brussels, Belgium
}

A R T I C L E I N F O

Article history:

Received 25 July 2010

Received in revised form 10 December 2012

Accepted 13 December 2012

\section{Keywords:}

Family firms

Divestment

Agency theory

\begin{abstract}
A B S T R A C T
This article examines how ownership, management and governance characteristics and the associated agency problems of family firms impact the divestment decision. Based on the divestment activity of 48 listed family firms in Belgium over a six-year period, I find an inverse U-shaped relationship between family ownership and divestment likelihood, supporting the alignment view at medium levels of family ownership but entrenchment at high ownership levels. In addition to ownership, the governance of the family firm also impacts the divestment decision. Divestiture likelihood is significantly lower when the family exerts its influence through the board of directors, consistent with the entrenchment view that they will use their influence to pursue non-economic goals. Founders, on the other hand, act as active monitors of the firm's activities and do not seem to be hindered by emotional considerations which result in more divestment activity as compared to other family firms.
\end{abstract}

(C) 2012 Elsevier Ltd. All rights reserved.

\section{Introduction}

Although divestitures are complex, high-impact events of great theoretical and practical interest, many issues still remain unresolved (Brauer, 2006). Family firms, one of the dominant organizational forms around the world, have received little attention in the existing divestiture research. This is quite surprising since virtually nothing is known of the divestment processes in family firms where decisions are governed as much by financial and rational motivations as they are by the emotional forces and family traditions (Sharma \& Manikutty, 2005). Knowing more about the divestiture process is crucial, though, since the timely adding to and shedding of the resource inventory is critical to securing long-term survival and creating a competitive advantage for family firms (Sirmon \& Hitt, 2003).

Furthermore, family firms are characterized by their involvement in ownership, control and management (Villalonga \& Amit, 2006). The impact of the family may not only be reflected in the percentage of shares held, though, but may alternatively or simultaneously show up in the governance characteristics of the family firm. Although inadequate governance has been shown to be an antecedent of divestment intensity in restructuring firms (Hoskisson, Johnson, \& Moesel, 1994), much is still inconclusive when it comes to the influence exercised by the governance characteristics on firm behavior (Chatterjee, Harrison, \& Bergh, 2003).

\footnotetext{
* Tel.: +32 0260982 50; fax: +3202217 6464 .

E-mail address: alain.praet@hubrussel.be
}

In addition to family ownership, it is also important to consider how family management impacts the divestment decision. Villalonga and Amit (2006) found that firm value is destroyed when descendants of family members serve as CEO. In their literature review, Sciascia and Mazzola (2008) state that the evidence is mixed for listed firms.

The theoretical lens used in the paper is agency theory, which is one of those most frequently applied in divestiture research, alongside portfolio theory and transaction cost economics (Brauer, 2006). Although this agency perspective has limitations, it is the dominant perspective in family business research (Pieper, 2010). Within the agency framework, two competing views have been developed, the alignment view and the entrenchment view (Wang, 2006). Applying agency theory on family firms allows distinguishing between these two perspectives, given the unique characteristics of family firms. According to the alignment view, the agency problems, typically described as a conflict between owners and managers, will diminish as blockholder ownership increases (Jensen \& Meckling, 1976). In family-controlled firms this type of agency conflict would be mitigated due to the families' greater incentives to monitor (Villalonga \& Amit, 2006).

On the other hand, the entrenchment view is based on the notion that family firms will be confronted with agency problems that differ in nature from those in non-family firms (Chrisman, Chua, \& Litz, 2004). As family ownership increases, a conflict may arise between the family and the minority shareholders (Villalonga \& Amit, 2006). Family relations also tend to make agency problems associated with owner management more difficult to resolve, due to self-control (Schulze, Lubatkin, Dino, \& Buchholtz, 2001). Socioemotional wealth considerations may also prevent family firms from divesting assets (Gomez-Mejia, Haynes, Nunez-Nickel, 
Jacobson, \& Moyano-Fuentes, 2007). As a result, this results in conservative behavior and is an exponent of the stagnation perspective (Miller, Le-Breton-Miller, \& Scholnik, 2008). Although an increased likelihood of divestiture is not necessarily positive, since overhasty divestitures may harm performance, on average divestiture actions are associated with positive performance outcomes for the divesting parent firm (Lee \& Madhavan, 2010).

Studying the divestment decision in family firms will thus reveal whether higher ownership levels and more involvement of the family in the board or the management align the family's interest with those of the other shareholders or are rather used to entrench themselves. Focusing on the combined impact of family ownership, governance characteristics and family management on the divestment likelihood in family firms will also show the importance of each of those elements in the divestment decision. Finally, the article also aims to contribute to the existing divestiture research, since little attention has been paid to the performance of the divested unit and samples outside the United States or the United Kingdom (Brauer, 2006).

This article proceeds as follows. First, I describe how family ownership and control affect the agency problems in family firms and the consequences for the divestment decision, resulting in an integrated set of hypotheses. The next sections then describe the data and the empirical results of the logistic regressions that estimate the divestment likelihood. Finally, the article ends with a conclusion, its limitations and directions for future research.

\section{Theoretical background and hypotheses development}

\subsection{Family ownership and control}

When families hold a controlling block of shares, this entails both benefits and costs, dependent on the perspective that is taken. According to the alignment view, the block of shares held by families increases their incentive to monitor the firm's activities (Demsetz \& Lehn, 1985). As a consequence, the traditional agency conflict between shareholders and management is mitigated in the case of family ownership (Jensen \& Meckling, 1976). Furthermore, family firms have special incentives to effectively manage the firm's financial capital (Gallo \& Vilaseca, 1996; McConaughy \& Phillips, 1999). This would lead to better performance as family ownership increases. However, the incentives of the family firm may alter as the ownership stake increases since socio-emotional considerations come into play and entrenchment may become their primary goal. This results in a non-linear relationship between family ownership and performance, as documented by Anderson and Reeb (2003) and Andres (2008). Ben-Amar and André (2006) also find a non-monotonic relationship between ownership level and the market's reaction to acquisition announcements. They interpret this as evidence of entrenchment at high levels of ownership.

On the other hand, it is important to consider the separate effect of family ownership, control and management (Villalonga \& Amit, 2006). Usually, families are actively involved in the management and the governance of the firm (Basu, Dimitrova, \& Paeglis, 2009). Through board representation, through the presence of a family member as CEO or chairman of the board, families are able to obtain additional control (Villalonga \& Amit, 2009). Governance, which is reflected in the board characteristics, is primarily an indirect antecedent of divestiture intensity (Hoskisson et al., 1994). Families can also exert a great deal of influence by placing one of their members in the position of CEO (Anderson \& Reeb, 2003). The evidence with respect to the impact of a family CEO has not been equivocal. On one hand, the presence of a family CEO has a positive impact on the market return upon the announcement of an acquisition (Ben-Amar \& André, 2006). However, Villalonga and
Amit (2006) find that firm performance suffers when the family firm is run by a descendant. This could be the consequence of altruism, which makes entrenchment more likely and prevents the appointment of a more capable professional manager (Schulze, Lubatkin, \& Dino, 2003).

The appointment of a member of the family as CEO or to a dominant position in the board will thus enable the family to pursue its own objectives. These goals can deviate from maximizing shareholder value, since firm performance may have a meaning to family firms which goes far beyond the financial numbers (Sharma \& Manikutty, 2005). In the same vein, Zellweger and Astrachan (2008) stress the importance of considering the emotional value of family ownership. Consequently, in family firms, a different type of agency problem may arise, since the potential conflict now is to be found in the different objectives of the controlling family and the minority shareholders in the firm (Faccio, Lang, \& Young, 2001; Morck \& Yeung, 2003). Family relations also tend to make agency problems associated with private ownership and owner management more difficult to resolve, due to self-control and other problems engendered by altruism (Schulze et al., 2001).

\subsection{Ownership and governance in the family firm and the divestment decision}

Given the diversity of ownership and governance characteristics within the group of family firms, the question remains as to how they influence the divestment process. Since decisions within family firms are governed as much by financial and rational motivations as they are by emotional forces and family traditions (Sharma \& Manikutty, 2005), ownership levels and the way the family firm is governed may reflect the emotional involvement of the family and impact the divestment process accordingly. So, if the emotional aspects outweigh the purely financial considerations, the entrenchment effect would be dominant, resulting in lower divestment likelihood.

Earlier evidence by Chrisman et al. (2004) suggests that overall agency problems in family firms may be less severe than in nonfamily firms. So, although emotional aspects may play an important role in family firms, strategic decisions will be driven by rational considerations about subsidiaries' performance and synergies with other group members. When family ownership is small, the ownership structure and governance will resemble those of a non-family firm and the traditional agency conflict between owners and managers will be predominant (Fama \& Jensen, 1983). Management will have a lot of discretion and most firms would benefit from refocusing (Chatterjee et al., 2003). However, as family ownership increases, the monitoring incentive of the family will increase accordingly and reduce the associated agency problems (Fama \& Jensen, 1983). As a result, the interests of the managers and family owners will be more aligned and the family will more readily divest activities that threaten family wealth or the survival of the family firm. When the level of family ownership becomes very high, however, the adoption of familycentered non-economic goals becomes more likely (Chrisman, Chua, Pearson, \& Barnett, 2012). Since family owners obtain nonpecuniary benefits, they might decide not to divest a subsidiary, even if it would increase the value of the firm. Even in public firms, maximizing family utility may dominate the goal of maximizing firm value (Bertrand \& Schoar, 2003). Also, at high levels of ownership, families can take decisions that are in their best interest but could be harmful to minority shareholders (Villalonga \& Amit, 2006). Based on the previous arguments, I expect that the entrenchment view will be most pertinent when the family is deeply involved in the firm through high ownership levels. These arguments thus suggest that the alignment effect will be most 
prominent as family ownership increases but that entrenchment will become dominant at high ownership levels which results in an inverted U-shaped relationship between divestment likelihood and family ownership.

Hypothesis 1. There will be an inverted U-shaped relationship between family ownership and divestment likelihood.

Villalonga and Amit (2006) also note that that family ownership only creates value when the founder serves as the CEO or as the chairman of the board with a hired CEO. The first generation also benefits from less severe agency problems (Blanco-Mazagatos, de Quevedo-Puente, \& Castrillo, 2007). This stems from the fact that ownership will normally be concentrated in the nuclear family which provides a strong incentive to maximize shareholder value. So founders will monitor activities more intensively than family firms where the founder is not present and will thus engage in more divestment activity. On the other hand, the founder may be willing to incur a great performance hazard in order to protect the level of socio-emotional wealth which will be high at this stage (Gomez-Mejia et al., 2007). However, since performance is only one factor in the divestment decision and given the more riskaverse and conservative behavior in case the firm goes from the first to the next generation (Molly, Laveren, \& Deloof, 2010), family firms where the founder is still present will be more likely to divest activities as compared to other family firms.

Hypothesis 2. Family firms in which the founder is still active are expected to be more likely to divest than other family firms.

Besides the presence of the founder, agency costs within family firms will also depend on the involvement of the family in management, which reflects family participation in strategic decision-making (Sciascia \& Mazzola, 2008). Anderson and Reeb (2003) find that active family involvement in management positions is associated with improved firm performance. Barontini and Caprio (2006), on the other hand, find that family firms where a descendant takes the position of CEO have similar valuation and performance to non-family firms. The importance of active family involvement is also stressed by Maury (2006), who states that active family control is associated with higher profitability as compared to non-family firms. Andres (2008) finds that outperformance by family firms is most pronounced in those firms where the family plays an active role. So when a family member occupies the CEO position, it can be expected that the firm's activities will be scrutinized more intensively. In summary, empirical evidence is relatively consistent with the alignment effect which implies that the presence of family members in a management position will increase the divestment likelihood.

Hypothesis 3a. Divestment likelihood in family firms in which a member of the family occupies the position of CEO is expected to be higher than in other family firms if the alignment hypothesis holds.

On the other hand, agency problems rooted in altruism and selfcontrol are exacerbated when the privileges of ownership place control of the firm's resources at the CEO's discretion (Schulze et al., 2001, 2003). These privileges create a variety of agency costs that can increase the need to monitor the work of family agents. Altruism also reduces the CEO's ability to effectively monitor and discipline family agents. Furthermore, at high ownership levels managerial entrenchment may prevent value-increasing decisions (Morck \& Yeung, 2003). An entrenched family CEO could thus be reluctant to divest, since the reduced level of business complexity would weaken his job security. Following Sirmon and Hitt (2003), it can also be argued that family firm's managers will be less likely than non-family managers to make appropriate shedding decisions, due to the emotional ties, nostalgia and/or escalation of commitment related to their unique social and human capital. The alignment effect of family involvement in management may thus be offset by the entrenchment effect induced by altruism and nepotism.

Hypothesis 3b. Divestment likelihood in family firms in which a member of the family occupies the position of CEO is expected to be lower than in other family firms if the entrenchment hypothesis holds.

Similarly, monitoring management by the owning family will also occur through the board of directors. Villalonga and Amit (2006) show that family firms with the founder as chairman of the board have the highest firm performance whereas the lowest performance is observed for firms in which a descendant occupies the position of chairman. However, Miller, Le Breton-Miller, Lester, and Cannella (2007) show that when lone-founders are removed from a sample of family firms, there is no longer evidence of superior market valuation. So although agency problems could be fewer when a member of the family holds the position of chairman, allowing the family to align its interests with those of the management, this does not result in a superior performance as compared to non-family firms. This could follow from the family's desire to pursue non-financial goals, as has been shown by e.g. Astrachan and Jaskiewicz (2008), Gomez-Mejia et al. (2007) and Zellweger and Astrachan (2008). Maximizing family utility instead of firm value can thus be expected, even for public firms (Bertrand \& Schoar, 2006). This entrenchment effect can be expected to be more pronounced as the percentage of family members on the board increases, since this will allow the family to impose its preferences. Divestitures would thus become less likely if the family appoints the chairman or as more family members occupy board positions.

Hypothesis 4a. Family firms in which the chairman of the board is a family member will have lower divestment likelihood than other family firms.

Hypothesis $\mathbf{4 b}$. Divestment likelihood and the percentage of family board members on the board will be negatively related.

Finally, according to agency theory, the monitoring function may be hampered when the same person holds the position of chairman of the board and CEO. Lack of CEO duality is associated with a more independent board and is expected to lead to more vigilant monitoring (Chatterjee et al., 2003). Empirical support for this proposition is provided by Yermack (1996) who documents that large industrial companies with a non-CEO chairman trade at higher price-to-book multiples. A metaanalysis of Dalton, Daily, Ellstrand, and Johnson (1998) does not confirm the agency view, though, since it does not show any significant relationship between board leadership structure and firm performance. Miller et al. (2007) also find no evidence that family firms, where a family member is both CEO and chairman, exhibit lower performance levels. On the other hand, when the same family member holds both the position of CEO and chairman, this will indicate a high level of family influence on the firm's strategy. This would allow the family to pursue nonfinancial objectives which would lead to less divestment activity to protect their socio-emotional wealth. Therefore, when the positions of chairman of the board and CEO are bestowed on the same individual in family firms, the entrenchment motive will be most prominent and divestment likelihood can be expected to be lower.

Hypothesis 5. Family firms characterized by CEO duality will have lower divestment likelihood as compared to other family firms. 


\section{Data and descriptive statistics}

\subsection{Data}

To explore how ownership, governance and family management affect divestment likelihood in listed family firms, a list of listed firms, as provided by the Statistics Department of the Brussels Stock Exchange, was made. To be included in the sample, the listed firms were required to have balance sheet data and data on their subsidiaries available with the 'Balanscentrale' for at least three years. The 'Balanscentrale' contains balance sheet data and profit and loss data in accordance with the Royal Decree of January $30,2001^{1}$ for all listed and non-listed non-financial companies in Belgium. This results in a total number of 133 listed firms, which include companies that have been delisted before 1996 to avoid a survivorship bias. Since banks and insurance companies are not obliged to publish their balance sheet data in the 'Balanscentrale' and given that listed banks and insurance companies are rarely family-owned, these firms are not included in the sample. Companies in liquidation are also excluded. The sample was further reduced because of the requirement that only listed firms holding a majority of the cash flow rights in non-financial subsidiaries were to be considered. This resulted in a final number of 87 listed firms. Data on the percentage held by blockholders in the listed firm were provided by the Statistics Department of the Brussels Stock Exchange. ${ }^{2}$

Afterwards, for each of these listed firms, the ultimate owner was initially identified following the methodology proposed by Renneboog (2000). When at least $10 \%$ of the shares were in the hands of families and the family was the dominant shareholder in the firm, it was considered to be family-owned. As a result a final sample of 48 listed family firms was obtained. Based on the notifications in accordance with the 'Ownership Disclosure Regulation', the median family owned 50\% of the voting rights as of 1991 . The minimum percentage held by families was $13.75 \%{ }^{3}$ In addition, for these listed family firms, information was collected in the annual reports and newspaper articles to verify whether the founder was still active in the firm. At the same time, the composition of the board in each year was examined to verify whether the CEO or the chairman of the board was a family member and the percentage of family members on the board was calculated.

To verify whether the listed family firm was involved in a divestment of a subsidiary in a particular year, I proceeded as follows. First of all, using the 'Balanscentrale' a list was made of all majority holdings for the listed family firms between 1991 and $1996 .{ }^{4}$ Subsequently, to identify the divested subsidiaries, for each listed company in the period considered a list was made of all subsidiaries no longer mentioned, which implies that they were either sold or liquidated. This procedure generated 251 subsidiaries

\footnotetext{
${ }^{1}$ Royal Decree "tot uitvoering van het Wetboek van vennootschappen". Previously, the Royal Decree of October 8, 1976.

2 Following the law of March 22, 1989, called the "Ownership Disclosure Law", investors have to make a notification to the Banking Commission (similar to the American SEC) if their voting rights reach a level of $5 \%$ in a company whose securities are traded on a stock exchange located in the European Union.

${ }^{3}$ An exception is Delhaize for which no notifications are made. Still the company is considered to be family-owned since press articles indicate that the family held approximately $35 \%$ of the shares in the 90 s. The family does not act as a syndicate, though, which relieves it from the obligation to make a notification. Additionally the annual report of 1998 indicates that descendants of the founders occupy 8 of the 10 board seats and the position of CEO.

4 The 'Balanscentrale' mentions minority as well as majority stakes. Although I had ownership data going back as far as 1986, balance sheet and income statement data were only available for the firms divested or liquidated from $1991 \mathrm{on}$. The data were available from the research I did for my $\mathrm{PhD}$ and were hand collected. Additionally, the period was interesting since it was the period used by a lot of US
} studies on divestitures (e.g. Bates, 2005). of family firms, of which 89 were divested by the listed family firms. When a listed family firm divested at least one subsidiary in a particular year, it was defined as being involved in a divestment. Data for the listed companies and their subsidiaries were obtained from the database of the National Bank, called 'Balanscentrale'.

\subsection{Control variables}

Since the firm- and unit-specific determinants of divestitures have been studied extensively in the strategic and financial literature, several control variables will be included in the logit regressions. A first determinant of divestitures that emerges from the literature is the presence of financial constraints (John, Lang, \& Netter, 1992; Kang \& Shivdasani, 1997; Lang, Poulsen, \& Stulz, 1995). Given a family's desire to maintain control of the firm and preserve it as a legacy for future generations (Gomez-Mejia et al., 2007), badly performing subsidiaries that threaten the survival of the family firm, will be more likely to be divested. To verify the impact of financial constraints and performance on the divestment likelihood, the median ratio of operating cash flow to total assets (CF) for the listed firm's subsidiaries is included.

An alternative explanation for the divestiture activity observed states that increasing focus motivates divestitures (Comment \& Jarrell, 1995; John \& Ofek, 1995; Wernerfelt \& Montgomery, 1988). Since unrelated assets may interfere with the seller's other assets, eliminating the resulting negative synergies leads to higher focus and better performance of the remaining assets. Additionally, Miller, Le Breton-Miller, and Lester (2010) argue that diversifying acquisitions need not be tightly integrated into a treasured legacy business. So divesting unrelated activities will only have a minor effect on the strategic focus and the corporate culture, which are key concerns to family firms (Miller \& Le Breton-Miller, 2005). To control for the focus motive, a variable is included that measures how diversified a listed firm is based on the 2-digit NACE code of its subsidiaries (DIVERSIF). The NACE-code of all subsidiaries was collected from the 'Balanscentrale'.

Two additional control variables are included in the regressions. First of all, a variable is included that proxies the size of the listed family firm. Since Maksimovic and Phillips (2001) and Schlingemann, Stulz, and Walkling (2002) find that relatively small segments are more likely to be divested, I include the median logarithm of total assets of the family firm's subsidiaries (SIZE) as a control variable. I also control for the age of the listed family firm by a binary variable (AGE) that has a value of 1 in case the family firm is less than 50 years old. Finally, all regressions include year and sector dummies but these coefficients are not reported for the sake of brevity.

\subsection{Descriptive statistics and methodology}

To verify the impact of ownership and governance characteristics of listed family firms on the likelihood that a subsidiary will be divested, logistic regressions are carried out. The dependent variable in the regressions is a binary variable that has a value of 1 if one or more subsidiaries are divested in the following year and 0 otherwise (DIVEST). As can be concluded from Table 1, family ownership (FAMOWN) was slightly higher than $50 \%$ in the median family firm. Additionally, the founder (FOUNDER) was present in about one-fourth of the family firms. With respect to the governance characteristics of the family firms, Table 1 shows that the family occupies, in approximately $70 \%$ of the family firms, the position of CEO (FAMCEO) or chairman of the board (FAMCHAIRMAN). In about one-third of the firms both positions

\footnotetext{
5 The NACE-code consists of 4 digits, is similar to the SIC-code and allows a sector classification for the subsidiaries.
} 
Table 1

Correlation matrix of family firm characteristics.

\begin{tabular}{|c|c|c|c|c|c|c|c|c|c|c|c|}
\hline & DIVEST & $\mathrm{CF}$ & SIZE & DIVERSIF & AGE & FAMOWN & FOUNDER & FAMCEO & $\begin{array}{l}\text { FAM- } \\
\text { CHAIRMAN }\end{array}$ & $\begin{array}{l}\text { \%FAM_ON_ } \\
\text { BOARD }\end{array}$ & $\begin{array}{l}\text { FAMCEO = } \\
\text { CHAIRMAN }\end{array}$ \\
\hline DIVEST & 1 & & & & & & & & & & \\
\hline $\mathrm{CF}$ & $-0.1262^{*}$ & 1 & & & & & & & & & \\
\hline SIZE & -0.0955 & 0.1024 & 1 & & & & & & & & \\
\hline DIVERSIF & $0.2339^{* * *}$ & -0.0843 & -0.0907 & 1 & & & & & & & \\
\hline AGE & 0.0269 & 0.0488 & -0.0327 & 0.1078 & 1 & & & & & & \\
\hline FAMOWN & 0.0199 & 0.0812 & $0.1143^{?}$ & $-0.2358^{* * *}$ & $0.2083^{* *}$ & 1 & & & & & \\
\hline FOUNDER & $0.1051^{?}$ & 0.0081 & $0.1828^{* * *}$ & -0.0489 & $0.4971^{* * *}$ & $0.2378^{* * * *}$ & 1 & & & & \\
\hline FAMCEO & -0.1019 & $0.1551^{* *}$ & 0.0299 & -0.0697 & $0.2006^{* *}$ & -0.0441 & -0.0216 & 1 & & & \\
\hline FAM-CHAIRMAN & $-0.1635^{* *}$ & $0.2553^{* * *}$ & -0.0131 & $-0.1201^{*}$ & $0.1814^{* *}$ & $-0.1540^{* * *}$ & $0.2016^{* *}$ & $0.2082^{* *}$ & 1 & & \\
\hline \%FAM_ON_BOARD & $-0.1855^{* *}$ & $0.2966^{* * *}$ & $-0.1621^{*}$ & $-0.1416^{*}$ & 0.0332 & -0.0711 & $-0.1007^{?}$ & $0.3199^{* * *}$ & $0.3550^{* * *}$ & 1 & \\
\hline FAMCEO = CHAIRMAN & -0.0271 & 0.0090 & 0.0135 & $-0.1183^{*}$ & $0.2627^{* * *}$ & $-0.1242^{*}$ & $0.2310^{* * *}$ & $0.5301^{* * *}$ & $0.4258^{* * *}$ & $0.1228^{*}$ & 1 \\
\hline Mean & 0.2015 & 0.0563 & 12.3064 & 0.4520 & 0.3172 & 47.3581 & 0.2345 & 0.6655 & 0.7552 & 0.3752 & 0.3586 \\
\hline Median & 0 & 0.0454 & 5.3614 & 0.5 & 0 & 50.01 & 0 & 1 & 1 & 0.3333 & 0 \\
\hline STDDEV & 0.4019 & 0.0742 & 1.3677 & 0.3583 & 0.4662 & 20.5117 & 0.4244 & 0.4726 & 0.4307 & 0.2185 & 0.4804 \\
\hline
\end{tabular}

? Significance at the $10 \%$ level.

Significance at 5\% level.

** Significance at $1 \%$ level.

Significance at less than $0.01 \%$.

$($ FAMCEO $=$ CHAIRMAN $)$ are held by the same family member. The family also holds one-third of the board seats in the median family firm (\%FAM_ON_BOARD).

The correlation coefficients in Table 1 show that the divestment variable is positively related to the presence of the founder in a significant way, but has no significant correlation with family ownership. In the group of governance variables, only the presence of a family chairman and the percentage of family members on the board show a significantly negative correlation with the divestment variable. Similarly, significantly negative correlations are presented between the divestment variable and the median subsidiaries' cash flow to total assets ratio. The ownership variable is positively related to the presence of a founder in a significant way, but is negatively related to having a family member as chairman. Having a family CEO is also positively related to having a family chairman, having more family members on the board and having CEO duality in a significant way.

\section{Empirical results}

To examine whether the percentage of shares held by the family significantly affects the divestment likelihood, the logistic regression in column 1 of Table 2 includes a variable which measures the percentage of shares held by the family (FAMOWN). The parameter estimate shows that divestment likelihood increases as families hold more shares, but the effect is not significant. To test for potential nonlinear effects, the squared term of the percentage of shares held by the family is added to the regressions in column 2 (FAMOWNSQR). The estimates show that divestment likelihood increases until the family holds a majority stake, but decreases afterwards when family ownership is very high. This can also be ascertained from Fig. 1 which shows an inverse U-shaped relationship between divestment likelihood and family ownership. Divestment likelihood increases to a maximum of $53.28 \%$ when the family owns $57 \%$ of the shares, but decreases when the family owns a larger ownership stake.

With respect to the control variables, the results in the first two columns of Table 2 confirm that lower profitability and a higher degree of diversification induce families to divest one or more subsidiaries the year afterwards. In each of the other logistic regressions these results stay qualitatively the same. Also, as the size of the median subsidiary increases, the divestment likelihood decreases in most regressions. Young family firms are also less likely to divest a subsidiary.
To verify whether the presence of the founder will lead to an increased divestment likelihood because of his superior monitoring ability or whether socio-emotional wealth considerations will dominate in the divestment decision, a dummy variable for this type of family firms is added in column 3 (FOUNDER). As expected, family firms have a significantly higher likelihood of divesting a subsidiary when the founder is present.

Besides through its ownership, the family can also exert its influence through the management or the governance of the family firm. When the CEO is a member of the controlling family, this may indicate increased alignment between management and shareholders or entrenchment. To verify which view holds, a dummy variable was added for those family firms where the CEO belongs to the family (FAMCEO). To distinguish the effect of a family member being CEO from the effect of the founder in the position of CEO, an additional dummy variable was added (FOUNDERCEO). The logistic regression results in column 4 of Table 2 reveal that a family member as CEO has a negative effect on divestment likelihood while a founder CEO has a positive effect, but this effect is in neither case significant.

Similarly, the impact of the presence of a family member as chairman of the board (FAMCHAIRMAN) on the divestment decision is investigated. Again a distinction is made dependent on whether the founder is the chairman (FOUNDERCHAIRMAN) or not. Column 5 of Table 2 reveals that a firm is significantly less likely to divest a subsidiary when the chairman of the board belongs to the controlling family, as was expected in Hypothesis 4a. At the same time, when the founder is the chairman of the board, divestment probability is significantly higher as compared to family firms where an outsider holds the position of chairman. When all variables are at their median level, the probability of a divestiture is $79.80 \%$ when the chairman is an outsider but only $59.27 \%$ when the chairman is a family member. When the founder is the chairman on the other hand, divestment likelihood increases to $92.03 \%$, again confirming the founder's role as a non-emotional guardian of firm value.

Similarly, column 6 of Table 2 reveals that divestment likelihood decreases significantly as the family occupies a larger percentage of the board seats. However, in family firms where the founder is present, no significant effect of family members on the board can be detected.

Finally, the monitoring function may be hampered when the same family member is both chairman of the board and CEO. The results in column 7 of Table 2 do not confirm the argument based 
Table 2

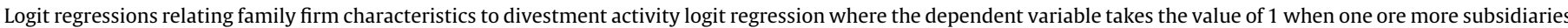

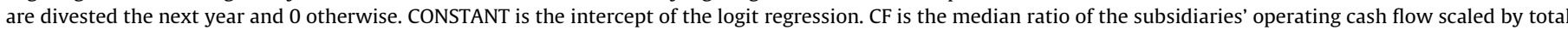

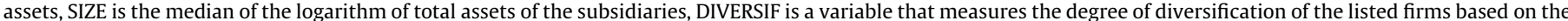

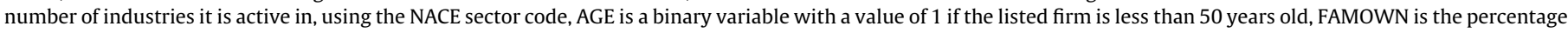

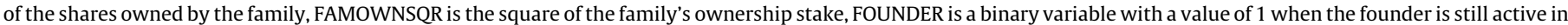

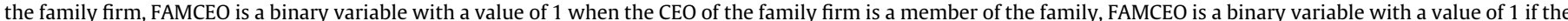

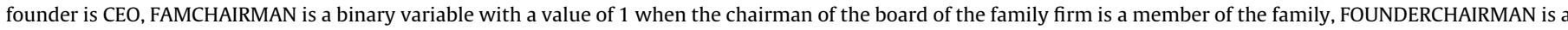

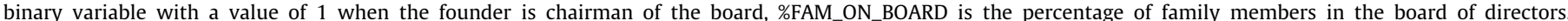

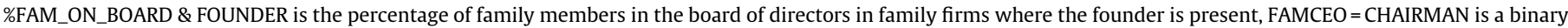

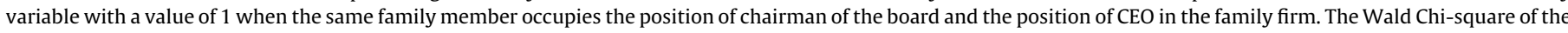
coefficients is mentioned in brackets. $\mathrm{N}^{\circ} \mathrm{Obs}$ is the number of observations used in the logit regression.

\begin{tabular}{|c|c|c|c|c|c|c|c|}
\hline & DIVEST & DIVEST & DIVEST & DIVEST & DIVEST & DIVEST & DIVEST \\
\hline CONSTANT & $\begin{array}{l}-1.2319 \\
(0.5948)\end{array}$ & $\begin{array}{l}-1.8029 \\
(1.1313)\end{array}$ & $\begin{array}{l}-0.8383 \\
(0.2371)\end{array}$ & $\begin{array}{l}-0.4683 \\
(0.0707)\end{array}$ & $\begin{array}{l}-0.3678 \\
(0.0414)\end{array}$ & $\begin{array}{l}0.0808 \\
(0.0019)\end{array}$ & $\begin{array}{l}-2.2417 \\
(1.5748)\end{array}$ \\
\hline $\mathrm{CF}$ & $\begin{array}{l}-5.6251 \\
(5.1072)^{*}\end{array}$ & $\begin{array}{l}-5.938 \\
(5.6107)^{*}\end{array}$ & $\begin{array}{l}-5.9902 \\
(5.4621)^{*}\end{array}$ & $\begin{array}{l}-6.0424 \\
(5.3729)^{*}\end{array}$ & $\begin{array}{l}-4.9661 \\
(3.3074)^{?}\end{array}$ & $\begin{array}{l}-4.2913 \\
(2.4252)\end{array}$ & $\begin{array}{l}-5.9626 \\
(5.6679)^{*}\end{array}$ \\
\hline SIZE & $\begin{array}{l}-0.1275 \\
(0.9992)\end{array}$ & $\begin{array}{l}-0.1726 \\
(1.7564)\end{array}$ & $\begin{array}{l}-0.2997 \\
(4.6944)^{*}\end{array}$ & $\begin{array}{l}-0.2386 \\
(3.1059)^{?}\end{array}$ & $\begin{array}{l}-0.2647 \\
(3.9355)^{*}\end{array}$ & $\begin{array}{l}-0.2976 \\
(4.6528)^{*}\end{array}$ & $\begin{array}{l}-0.1813 \\
(1.8969)\end{array}$ \\
\hline DIVERSIF & $\begin{array}{l}2.5622 \\
(15.4832)^{* * *}\end{array}$ & $\begin{array}{l}2.4338 \\
(13.861)^{* *}\end{array}$ & $\begin{array}{l}2.7942 \\
(17.0698)^{* * *}\end{array}$ & $\begin{array}{l}2.5640 \\
(15.2089)^{* * *}\end{array}$ & $\begin{array}{l}2.8475 \\
(16.122)^{* * *}\end{array}$ & $\begin{array}{l}2.6271 \\
(15.6088)^{* * *}\end{array}$ & $\begin{array}{l}2.6053 \\
(14.7972)^{* * *}\end{array}$ \\
\hline AGE & $\begin{array}{l}0.0438 \\
(0.014)\end{array}$ & $\begin{array}{l}-0.0786 \\
(0.0431)\end{array}$ & $\begin{array}{l}-0.7586 \\
(2.824)^{?}\end{array}$ & $\begin{array}{l}-0.3997 \\
(0.8633)\end{array}$ & $\begin{array}{l}-0.9606 \\
(3.5715)^{?}\end{array}$ & $\begin{array}{l}-0.8730 \\
(3.6223)^{?}\end{array}$ & $\begin{array}{l}-0.2159 \\
(0.2879)\end{array}$ \\
\hline FAMOWN & $\begin{array}{l}0.0108 \\
(1.3293)\end{array}$ & $\begin{array}{l}0.0703 \\
(3.2561)^{?}\end{array}$ & $\begin{array}{l}0.0845 \\
(4.1844)^{*}\end{array}$ & $\begin{array}{l}0.0630 \\
(2.5558)\end{array}$ & $\begin{array}{l}0.0816 \\
(3.7665)^{?}\end{array}$ & $\begin{array}{l}0.1206 \\
(6.7712)^{* *}\end{array}$ & $\begin{array}{l}0.0831 \\
(3.8424)^{*}\end{array}$ \\
\hline FAMOWNSQR & & $\begin{array}{l}-0.00062 \\
(2.5849)\end{array}$ & $\begin{array}{l}-0.0008 \\
(3.6529)^{?}\end{array}$ & $\begin{array}{l}-0.0006 \\
(2.4063)\end{array}$ & $\begin{array}{l}-0.00082 \\
(4.0195)^{*}\end{array}$ & $\begin{array}{l}-0.0012 \\
(6.7575)^{* *}\end{array}$ & $\begin{array}{l}-0.0007 \\
(3.0548)^{?}\end{array}$ \\
\hline FOUNDER & & & $\begin{array}{l}1.5627 \\
(10.054)^{* *}\end{array}$ & & & & \\
\hline FAMCEO & & & & $\begin{array}{l}-0.6088 \\
(2.4604)\end{array}$ & & & \\
\hline FOUNDER CEO & & & & $\begin{array}{l}0.8099 \\
(1.9618)\end{array}$ & & & \\
\hline FAM-CHAIRMAN & & & & & $\begin{array}{l}-0.9987 \\
(5.1408)^{*}\end{array}$ & & \\
\hline FOUNDERCHAIRMAN & & & & & $\begin{array}{l}1.0733 \\
(3.1180)^{?}\end{array}$ & & \\
\hline \%FAM_ON_BOARD & & & & & & $\begin{array}{l}-4.2195 \\
(13.7061)^{* *}\end{array}$ & \\
\hline \%FAM_ON_BOARD \& FOUNDER & & & & & & $\begin{array}{l}-0.0588 \\
(0.0025)\end{array}$ & \\
\hline FAMCEO = CHAIRMAN & & & & & & & $\begin{array}{l}0.4235 \\
(1.1262)\end{array}$ \\
\hline $\mathrm{N}^{\circ} \mathrm{Obs}$ & 250 & 250 & 250 & 250 & 250 & 250 & 250 \\
\hline Chi-square & $25.0509^{* * *}$ & $27.9857^{* * *}$ & $38.2460^{* * *}$ & $35.2542^{* * *}$ & $42.0566^{* * *}$ & $47.6463^{* * *}$ & $29.1131^{* * *}$ \\
\hline
\end{tabular}

? Significance at the $10 \%$ level.

* Significance at $5 \%$ level.

** Significance at $1 \%$ level.

Significance at less than $0.01 \%$

on agency theory that monitoring will happen more efficiently when the chairman is not the CEO. Although divestment likelihood is higher in the event that the function of CEO and chairman is bestowed by the same person, the difference is not statistically significant, contrary to the expectation of Hypothesis 5. Although

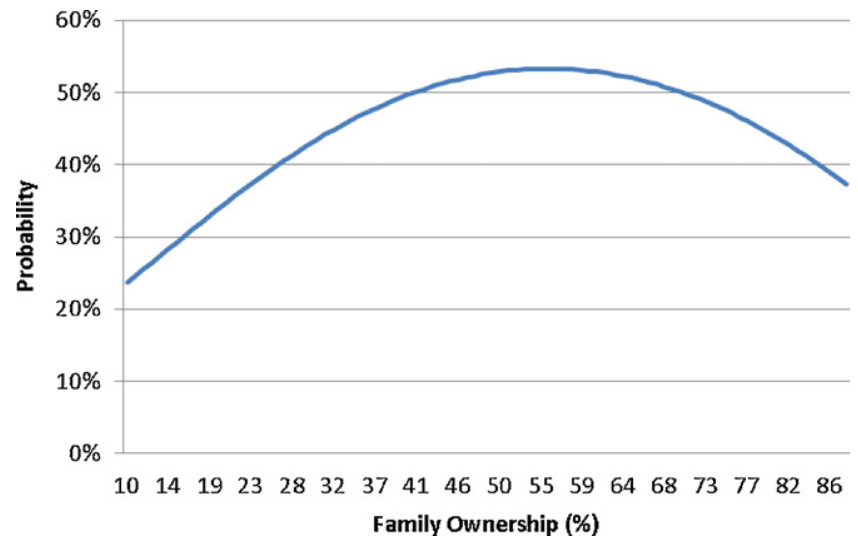

Fig. 1. The relationship between family ownership and divestment probability. the family increases its potential to influence the firm's strategy through the function of CEO and chairman, no evidence is found for lower divestment likelihood.

\section{Discussion and conclusion}

This article has shown that both ownership and governance characteristics and the associated agency problems within the group of family firms have a significant impact on the decision to divest one or more subsidiaries.

On one hand, the level of family influence will depend on the families' level of ownership. As family ownership increases, the divestment likelihood increases also, consistent with the alignment view. However, when family ownership becomes very high, divestment likelihood decreases which supports the entrenchment view. This means that increasing the level of ownership initially provides an incentive to the family to monitor more intensively, but at high levels of ownership the family will pursue its own objectives and avoid divestments to protect its socioemotional wealth. This curvilinear relationship between ownership and divestment probability thus adds to the growing evidence of nonlinear relationships between family ownership and performance (Anderson \& Reeb, 2003; Sciascia \& Mazzola, 
2008), family ownership and international entrepreneurship (Sciascia, Mazzola, Astrachan, \& Pieper, 2012) and the dispersion of ownership among directors in family firms and the use of debt (Schulze et al., 2003).

It is also interesting to note that the founder clearly has different objectives as compared to other family firms. Consistent with Hypothesis 2 and the earlier evidence that founders outperform other types of family firms (Miller et al., 2007, Villalonga \& Amit, 2006), I find that founders are more likely to divest a subsidiary. So founders appear to have superior monitoring abilities and the alignment view is supported. They will intervene sooner when things are going the wrong way, contrary to the expectation that emotional attachment to the activities they started would prohibit divestment. When control is in the hands of descendants, organizational changes by means of divestitures become less likely.

Besides ownership, divestment likelihood may also depend on the involvement by the family in the management of the firm. However, the results show that when the CEO is a family member, this does not seem to impact the divestment decision. Although the results support the entrenchment view when a family member is the CEO, consistent with the propositions of Sirmon and Hitt (2003), the coefficient is not significant. Non-founder CEOs that are also family members thus seem to have no disadvantage relative to hired CEOs and do not differ in their monitoring ability from nonfamily CEOs. Although occupying the CEO position increases the control of the family over the firm, there is only weak evidence that they will use their power to pursue non-economic goals. When the founder is the CEO on the other hand, the results are supportive of the alignment view, although again the coefficient is not significant.

Finally, besides ownership and management, the way the family governs the firm also significantly impacts the strategic decisions. The results show that the family will exert its influence, and its desire to preserve the socio-emotional wealth of the family, mainly through the board of directors. When the family holds the position of chairman of the board or as the family occupies more board seats, it will reduce the divestment likelihood as expected in Hypotheses $4 \mathrm{a}$ and 4b. Scrutinizing managers' behavior thus happens more adequately when an external chairman is hired since the family appears to use its influence to hold on to activities for non-financial reasons. The board thus seems to be an instrument for the family to exert its influence and maximize family utility in public firms, as suggested by Bertrand and Schoar (2006), and entrench themselves. Again, the situation is different when the founder is involved. When the founder is present and occupies the position of chairman, divestment likelihood is significantly higher while no significant effect of the percentage of family members on the board is observed.

The article thus contributes to the scarce evidence on the divestment decision in family firms and disentangles the alignment view from the entrenchment view within the agency framework. It demonstrates that the alignment view is most pertinent at moderate levels of family ownership and when the founder is still present in the family firm. At very high ownership levels and when the percentage of family members on the board increases, entrenchment becomes the dominant motive. This is in line with earlier evidence by Ben-Amar and André (2006) on the entrenchment effect in case of acquisitions. The article also considers not only ownership as exercised by the family but also the management and governance characteristics of the listed family firms. It thus adds to the discussion about the channels through which the families influence strategic decisions in firms. The results show that the board of directors is the main instrument, rather than the CEO position, to influence the strategic decision in Belgian listed family firms. The results also confirm earlier evidence that founders play a unique role and have capabilities that should be fostered. That way, the article contributes to the need for a deepened understanding about the divestment decision in family firms outside the US or UK.

Notwithstanding its contribution, the article also has some limitations that at the same time provide avenues for future research. The focus of this study on Belgium and the use of a sixyear period make it necessary to validate these results for other countries and for other time periods. In this respect, future research might investigate how the financial crisis has influenced the governance of listed family firms and the divestment decisions taken. It is unclear whether the tendency of a family to pursue nonfinancial objectives and entrench themselves will continue to be equally important in times of financial distress. So, not only the subsidiaries' financial situation but also the parent firm's characteristics might influence the divestment decision.

Moreover, since this study focused on publicly listed family firms, it would be interesting to see whether the results obtained here also hold in non-listed firms. Since non-listed firms are not subject to capital market scrutiny, socio-emotional considerations could be expected to influence the divestment decision to a large extent. Focusing on how the family influences the strategic decisions, through its presence in management or through the board of directors, could be a fruitful avenue for future research. Similarly, a comparison between the divestment decision in family firms and non-family firms and the factors that have an impact on it, could add to the research that investigates the differences between those type of firms.

Also, in the regressions the assumption was made that the decision to divest a subsidiary was based on the previous year's characteristics, but in reality it is likely that performance over a longer time period will be considered. A case-study approach on the different steps in the divestment process in listed as well as non-listed family firms could reveal new insights in this issue.

Additionally, besides the governance characteristics considered here, other governance measures and their impact on the divestment decision could be investigated. Including the ownership of the board members and the CEO or the degree of ownership concentration could add to the existing evidence on the relevance of these factors (Bergh, 1995). Finally, this study focused on divestitures as a restructuring strategy, but it is clear that families can also choose different forms of reorganization. Future research therefore could consider the different alternatives available and how families choose between them.

\section{Acknowledgments}

I am grateful to Henri Servaes, Jan Degadt, Johan Lambrecht, the editor and co-editor of this journal and two anonymous referees for helpful comments, as well as GRAYDON Belgium for providing data.

\section{References}

Andres, C. (2008). Large shareholders and firm performance-An empirical examination of founding-family ownership. Journal of Corporate Finance, 14(4), 431-445. Anderson, R. C., \& Reeb, D. M. (2003). Founding family ownership and firm performance: Evidence from the S\& P 500. Journal of Finance, 58(3), 1301-1328.

Astrachan, J. H., \& Jaskiewicz, P. (2008). Emotional returns and emotional costs in privately held family businesses: Advancing traditional business valuation. Family Business Review, 21(2), 139-149.

Barontini, R., \& Caprio, L. (2006). The effect of family control on firm value and performance: Evidence from Continental Europe. European Financial Management, 12(5), 689-723.

Basu, N., Dimitrova, L., \& Paeglis, I. (2009). Family control and dilution in mergers. Journal of Banking and Finance, 33(5), 829-841.

Bates, T. W. (2005). Asset sales, investment opportunities and the use of proceeds. Journal of Finance, 60(1), 105-135.

Ben-Amar, W., \& André, P. (2006). Separation of ownership from control and acquiring firm performance: The case of family ownership in Canada. Journal of Business Finance \& Accounting, 33(3-4), 517-543. 
Bergh, D. D. (1995). Size and relatedness of units sold: An agency theory and resourcebased perspective. Strategic Management Journal, 16(3), 221-239.

Bertrand, M., \& Schoar, A. (2003). Managing with style: The effect of managers on firm policies. Quarterly Journal of Economics, 118(4), 1169-1208.

Bertrand, M., \& Schoar, A. (2006). The role of family in family firms. Journal of Economic Perspectives, 20(2), 73-96.

Blanco-Mazagatos, V., deQuevedo-Puente, E., \& Castrillo, L. A. (2007). The trade-off between financial resources and agency costs in the family business: An exploratory study. Family Business Review, 20(3), 199-213.

Brauer, M. (2006). What have we acquired and what should we acquire in divestiture research? A review and research agenda. Journal of Management, 32(6), 751-785.

Chatterjee, S., Harrison, J. S., \& Bergh, D. D. (2003). Failed takeover attempts, corporate governance and refocusing. Strategic Management Journal, 24(1), 87-96.

Chrisman, J. J., Chua, J. H., \& Litz, R. A. (2004). Comparing the agency costs of family and non-family firms: Conceptual issues and exploratory evidence. Entrepreneurship Theory \& Practice, 28(4), 335-354.

Chrisman, J. J., Chua, J. H., Pearson, A. W., \& Barnett, T. (2012). Family involvement, family influence, and family-centered non-economic goals in small firms. Entrepreneurship, Theory \& Practice, 36(2), 267-293.

Comment, R., \& Jarrell, G. A. (1995). Corporate focus and stock returns. Journal of Financial Economics, 37(1), 67-87.

Dalton, D. R., Daily, C. M., Ellstrand, A. E., \& Johnson, J. L. (1998). Meta-analytic reviews of board composition, leadership structure and financial performance. Strategic Management Journal, 19(3), 269-290.

Demsetz, H., \& Lehn, K. (1985). The structure of corporate ownership: Causes and consequences. Journal of Political Economy, 93(6), 1155-1177.

Faccio, M., Lang, L. H. P., \& Young, L. (2001). Dividends and expropriation. American Economic Review, 91(1), 54-78.

Fama, E., \& Jensen, M. C. (1983). Separation of ownership and control. Journal of Law \& Economics, 26, 301-325.

Gallo, M. A., \& Vilaseca, A. (1996). Finance in family business. Family Business Review, 9(4), 387-401.

Gomez-Mejia, L. R., Haynes, K. T., Nunez-Nickel, M., Jacobson, K. J. L., \& MoyanoFuentes, J. (2007). Socioemotional wealth and business risks in family-controlled firms: Evidence from Spanish olive oil mills. Administrative Science Quarterly, 52(1), $106-137$.

Hoskisson, R. E., Johnson, R. A., \& Moesel, D. D. (1994). Corporate divestiture intensity in restructuring firms: Effects of governance, strategy, and performance. Academy of Management Journal, 37(5), 1207-1251.

Jensen, M. C., \& Meckling, W. H. (1976). Theory of the firm: Managerial behaviour, agency costs and ownership structure. Journal of Financial Economics, 3(4), 305-360.

John, K., Lang, L. H. P., \& Netter, J. (1992). The voluntary restructuring of large firms in response to performance decline. Journal of Finance, 47(3), 891-917.

John, K., \& Ofek, E. (1995). Asset sales and increase in focus. Journal of Financial Economics, 37(1), 105-126.

Kang, J.-K., \& Shivdasani, A. (1997). Corporate restructuring during performance declines in Japan. Journal of Financial Economics, 46(1), 29-65.

Lang, L., Poulsen, A., \& Stulz, R. (1995). Asset sales, firm performance and the agency costs of managerial discretion. Journal of Financial Economics, 37(1), 3-37.

Lee, D., \& Madhavan, R. (2010). Divestiture and firm performance: A meta-analysis. Journal of Management, 36(6), 1345-1371.

Maksimovic, V., \& Phillips, G. (2001). The market for corporate assets: Who engages in mergers and asset sales and are there efficiency gains? Journal of Finance, 56(6), 2019-2065.
Maury, B. (2006). Family ownership and firm performance: Empirical evidence from Western European corporations. Journal of Corporate Finance, 12(2), 321-341.

McConaughy, D., \& Phillips, G. (1999). Founders versus descendants: The profitability, efficiency, growth characteristics, and financing in large, public, founding-familycontrolled firms. Family Business Review, 12(2), 123-132.

Miller, D., \& Le Breton-Miller, I. (2005). Managing for the long run. Boston, MA: Harvard Business School Press.

Miller, D., Le Breton-Miller, I., \& Lester, R. H. (2010). Family ownership and acquisition behavior in publicly-traded companies. Strategic Management Journal, 31(2), 201-223.

Miller, D., Le Breton-Miller, I., Lester, R. H., \& Cannella, A. A., Jr. (2007). Are family firms really superior performers? Journal of Corporate Finance, 13(5), 829-858.

Miller, D., Le Breton-Miller, I., \& Scholnik, B. (2008). Stewardship vs. stagnation: An empirical comparison of small family and non-family businesses. Journal of Management Studies, 45(1), 51-78.

Molly, V., Laveren, E., \& Deloof, M. (2010). Family business succession and its impact on financial structure and performance. Family Business Review, 23(2), 131-147.

Morck, R., \& Yeung, B. (2003). Agency problems in large family business groups. Entrepreneurship Theory \& Practice, 27(4), 367-382.

Pieper, T. (2010). Non solus: Toward a psychology of family business. Journal of Family Business Strategy, 1(1), 26-39.

Renneboog, L. (2000). Ownership managerial control and the governance of companies listed on the Brussels Stock Exchange. Journal of Banking and Finance, 24(12), 19591995.

Sciascia, S., \& Mazzola, P. (2008). Family involvement in ownership and management: Exploring nonlinear effects on performance. Family Business Review, 21(4), 331-345.

Sciascia, S., Mazzola, P., Astrachan, J. H., \& Pieper, T. M. (2012). The role of family ownership in international entrepreneurship: Exploring nonlinear effects. Smal Business Economics, 38(1), 15-31.

Schlingemann, F., Stulz, R. M., \& Walkling, R. A. (2002). Asset liquidity and segment divestitures. Journal of Financial Economics, 64(1), 117-144.

Schulze, W. S., Lubatkin, M. H., \& Dino, R. N. (2003). Exploring the agency consequences of ownership dispersion among the directors of private family firms. Academy of Management Journal, 46(2), 179-194.

Schulze, W. S., Lubatkin, M. H., Dino, R. N., \& Buchholtz, A. K. (2001). Agency relationships in family firms: Theory and evidence. Organization Science, 12(2), 99-116.

Sharma, P., \& Manikutty, S. (2005). Strategic divestments in family firms: Role of family structure and community culture. Entrepreneurship Theory E Practice, 29(3), 293-311.

Sirmon, D. G., \& Hitt, M. A. (2003). Managing resources: Linking unique resources, management, and wealth creation in family firms. Entrepreneurship Theory $\mathcal{E}$ Practice, 27(4), 339-358.

Villalonga, B., \& Amit, R. (2006). How do family ownership, control, and management affect firm value? Journal of Financial Economics, 80(2), 385-417.

Villalonga, B., \& Amit, R. (2009). How are U.S. family firms controlled? Review of Financial Studies, 22(8), 3047-3091.

Wang, D. (2006). Founding family ownership and earnings quality. Journal of Accounting Research, 44(3), 619-656.

Wernerfelt, B., \& Montgomery, C. A. (1988). Tobin's q and the importance of focus in firm performance. American Economic Review, 78(1), 246-250.

Yermack, D. (1996). Higher valuation of companies with a small board of directors. Journal of Financial Economics, 40(2), 185-212.

Zellweger, T. M., \& Astrachan, J. H. (2008). On the emotional value of owning a firm. Family Business Review, 21(3), 347-363. 